\title{
Mathematical modeling of whey foam mat drying ${ }^{1}$
}

\author{
Fernanda Machado Baptestini $2^{*} \mathbb{1}$, Paulo Cesar Corrêa $a^{3}$, Juliana Soares Zeymer ${ }^{3}$, Rildo Araújo Leite ${ }^{4}$, \\ Jaime Daniel Bustos-Vanegas ${ }^{3}$, Gheila Corrêa Ferres Baptestini ${ }^{5}$
}

$10.1590 / 0034-737 X 202168040006$

\begin{abstract}
This study aimed to fit mathematical models to whey foam drying processes in different air temperature conditions, to determine the effective diffusion coefficient and to obtain the activation energy. For foam formation, 5.0\% Emustab ${ }^{\circledR}$ was added to the serum in mass and subjected to stirring in a domestic shaker for $15 \mathrm{~min}$. After, it was spread onto trays to form a thin layer of about $1 \mathrm{~cm}$ in which the drying conditions were: $40,45,50,55$ and $60{ }^{\circ} \mathrm{C}, 5.6 \mathrm{~m} \mathrm{~s}^{-1}$ and $60 \%$. The Logarithm and Midilli models describe the kinetics of serum foam drying; the effective diffusion coefficient increased with the elevation of drying temperature and activation energy of $50.84 \mathrm{~kJ} \mathrm{~mol}^{-1}$.
\end{abstract}

Keywords: activation energy; critical moisture content; drying rate; foam.

\section{INTRODUCTION}

Milk production and milk and dairy processing are important activities that generate employment and income for those involved in this production chain. According to data from ABIQ (Brazilian Association of Cheese Industries), in 2017, the Brazilian cheese production exceeded 1 million tons, increasing 2\% over 2016 (Foodnews, 2018). Considering that, on average, ten liters of milk produce about one kilo of cheese and nine liters of whey, the approximate production resulted in 9 million liters of whey in 2017.

Part of the large volume of whey produced in Brazil, mainly by small and medium-sized cheese factories, is thrown directly into the water bodies causing serious damage to the environment for being highly polluting. The other is intended for animal feeding. In addition, this disposal compels the country to import a high volume of co-products, since its processing requires the application of technologies still not very adapted to the national reality. Therefore, studying alternatives to processing this product, besides solving the problems already mentioned, enables value aggregation and increases the competitiveness and sustainability of low and middle-income rural communities.
According to Alves et al., (2014) whey accounts for $80-90 \%$ total milk volume used during cheese production, and contains approximately 55\% milk nutrients: soluble proteins, lactose, vitamins, minerals and a minimum amount of fat. Serum can be used in its original form, to produce dairy beverage. However, serum can be concentrated considering its high-water content and the purpose of adding value to the product and its derivatives. The concentrated product is then classified according to the protein content and may have various applications due to its nutritional and technological characteristics ranging from its use as a food ingredient to the production of medicine.

The main unit operations for obtaining powder whey may be the combination of membrane filtration, vacuum evaporation, crystallization and spray dryer. Reverse osmosis can be used as the initial phase of water withdrawal from the serum and has low energy consumption (Perrone et al., 2011). However, these technologies are expensive and difficult to handle for small and mediumsized producers, thus enabling the introduction of new forms of processing or adapting those already in use, such as foam mat drying.

\footnotetext{
Submitted on February 17th, 2020 and accepted on June 11th, 2021.

This work is part of the first author Post-Doctoral report.

${ }^{2}$ Universidade Federal do Espírito Santo, Departamento de Engenharia Rural, Alegre, Espírito Santo, Brazil. fernanda.baptestini@ufes.br

${ }^{3}$ Universidade Federal de Viçosa, Departamento de Engenharia Agrícola e Ambiental, Viçosa, Minas Gerais, Brazil. copace@ufv.br; juliana.zeymer@ufv.br; jdbustosv@misena.co

${ }^{4}$ Instituto Federal do Norte de Minas Gerais, Arinos, Minas Gerais, Brazil. rildo.leite@ifnmg.edu.br

${ }^{5}$ Instituto Federal de Espírito Santo, Santa Maria de Jetibá, Espírito Santo, Brazil. gheilacf@yahoo.com.br

*Corresponding author: fernanda.baptestini@ufes.br
} 
In the foam mat drying method, food is transformed into a stable foam by the addition of blowing agents and the incorporation of air, nitrogen or other gases into blenders or other foam generating equipment (Fellows, 2006). Thereafter, the foam is spread over a surface, drilled or not, generally with a thick layer of about 2 to $5 \mathrm{~mm}$. Drying results in a porous and brittle product, easy grinding and powder transformation with good rehydration properties (Bastos et al., 2005).

Therefore, the study of processing technologies such as foam mat drying is an alternative to create a source of income, which allows the use of whey in a feasible way, both economically and technologically. In addition, according to Perrone (2010), the development of operational and technological attributes to process whey powder is necessary in the national industry of concentrates and derivatives. Welldesigned machinery and process lines will contribute to a greater competitiveness of these industries in the national and international markets, as well as the better serum use. Thus, the objective of this work was to obtain and model the drying curves and to determine the effective diffusion coefficient and the activation energy of the whey foam-mat drying in temperatures between 40 and $60^{\circ} \mathrm{C}$.

\section{MATERIAL AND METHODS}

The whey was obtained from FUNARBE/UFV DairySchool and stored in PET bottles in a freezer at $-18^{\circ} \mathrm{C}$. The whey was previously sanitized with water and chlorine solution.

For foam formation, from preliminary tests, $5.0 \%$ Emustab ${ }^{\circledR}$ was added to the serum, in mass and subjected to stirring in a domestic shaker.

The formed foam was spread on trays forming a thin layer of about $1.0 \mathrm{~cm}$ in thickness. Thereafter, the foam was placed for drying in a forced air circulation oven in which temperatures, speed and average relative humidity of the inlet air were $40,45,50,55$ and $60{ }^{\circ} \mathrm{C}, 5.6 \mathrm{~m} \mathrm{~s}^{-1}$ and $60 \%$, respectively.

To determine the binomial critical moisture content and the critical time, we used Equation 1, adapted from Stupa et al. (2003) and Reis et al. (2013), which describes the period of constant rate and the period of decreasing rate, separated by the critical time.

$U_{t}=\left[U_{o}-(n t)\right]\left(t<t_{c}\right)+\left\{U_{c} \exp \left[-k\left(t-t_{c}\right)\right]\right\}\left(t \geq t_{c}\right)$

in which: $\mathrm{U}_{\mathrm{c}}$ - critical moiture content, $\mathrm{kg}_{\mathrm{a}} \mathrm{kg}_{\mathrm{dm}}{ }^{-1} ; \mathrm{U}_{\mathrm{t}}$ moisture content at $\mathrm{t}$ time, $\mathrm{kg}_{\mathrm{a}} \mathrm{kg}_{\mathrm{dm}}{ }^{-1} ; \mathrm{n}$ - drying rate at constant period, $\min ^{-1} ; \mathrm{U}_{0}$ - initial moisture content, $\mathrm{kg}_{\mathrm{a}}$ $\mathrm{kg}_{\mathrm{dm}}{ }^{-1} ; \mathrm{k}$ - drying rate at decreasing period, $\mathrm{min}^{-1} ; \mathrm{t}_{\mathrm{c}}$ - critical time, $\min$.
The moisture ratio (MR) was determined according to Equation 2.

$M R=\frac{U_{t}-U_{e}}{U_{o}-U_{e}}$

in which: $\mathrm{Ue}$ - moisture content at balance, $\mathrm{kg}_{\mathrm{a}} \mathrm{kg}_{\mathrm{dm}}{ }^{-1}$.

Adjustments were made in the mathematical models used to describe the drying phenomenon to the experimental data of the serum foam drying (Table 1).

The effective diffusion coefficient was obtained by adjusting the mathematical model of the net diffusion, described in Equation 3.

$M R=\frac{U_{t}-U_{e}}{U_{o}-U_{e}}=\frac{8}{\pi^{2}} \sum_{n=0}^{\infty} \frac{1}{(2 n+l)^{2}} \exp \left[-\frac{(2 n+1)^{2} \pi^{2} D_{e f t}}{4 L^{2}}\right]$

in which: L - product thickness, m; Def - effective diffusion coefficient, $\mathrm{m}^{2} \mathrm{~s}^{-1} ; \mathrm{n}$ - number of terms of the equation.

The analytical solution of this equation is in the form of an infinite series.

Therefore, the finite number of terms (n) in truncation determines the result accuracy. This number was five $(n=$ 5 ), as the effective diffusion coefficient did not change for higher values of (n).

To evaluate the temperature influence on the effective diffusion coefficient, the Arrhenius ratio, Equation 4 was used.

$D_{e f}=D_{o} \exp \left(-\frac{E_{a}}{R T_{a}}\right)$

in which: $\mathrm{D}_{0}$ - pre-exponential factor, $\mathrm{m}^{2} \mathrm{~s}^{-1} ; \mathrm{E}_{\mathrm{a}}$ - activation energy, $\mathrm{kJ} \mathrm{mol}^{-1} ; \mathrm{R}$ - universal constant of gases, 8,314 J $\mathrm{mol}^{-1} \mathrm{~K}^{-1} ; \mathrm{T}_{\mathrm{a}}$ - absolute temperature, $\mathrm{K}$.

The experiment was carried out in a completely randomized design with five replications. The experimental data on serum foam drying were submitted to nonlinear regression analysis and to the selection of the appropriate model to express the relationship between the studied variables.

In order to analyze the adjustment degree of each model, it was considered the coefficient of determination, mean relative error (MRE), estimated mean error (EME), Equations 5 and 6, respectively, and residue distribution (RD).

MRE $=\frac{100}{n} \sum_{i=1}^{n} \frac{\left|Y_{i}-\hat{Y}_{i}\right|}{Y_{i}}$

$E M E=\sqrt{\frac{\sum_{i=1}^{n}\left(Y_{i}-\hat{Y}_{i}\right)^{2}}{R D F}}$

in which: Yi - observed value; Yi - estimated value; $\mathrm{n}$ number of observed data; RDF - residue degree of freedom. 
Table 1: Mathematical models used to model the whey foam drying

\begin{tabular}{lll}
\hline Model & \multicolumn{1}{c}{ Model designation } \\
\hline$M R=a \exp (-k t)+(1-a) \exp (-k a t)$ & Exponential of two terms (Sharaf-Eldee et al., 1980) & $(7)$ \\
$M R=a \exp (-k t)$ & Henderson and Pabis (Henderson \& Pabis, 1961) & $(8)$ \\
$M R=a \exp (-k t)+b$ & Logarithmic (Yagcioglu et al., 1999) & $(10)$ \\
$M R=a \exp (-k t)+b t$ & Midilli (Midilli, 2002) & $(11)$ \\
$M R=\exp (-k t)$ & Newton (Lewis, 1921) & $(12)$ \\
$M R=\exp \left(-k t^{n}\right)$ & Page (Page, 1949) & \\
\hline
\end{tabular}

Where: $\mathrm{t}$ - drying time, min; $\mathrm{k}$ - drying rate, $\min ^{-1} ; \mathrm{a}, \mathrm{b}, \mathrm{n}$ - model parameters, dimensionless

\section{RESULTS AND DISCUSSION}

Figure 1 shows the whey foam drying curves at 40, 45, 50,55 and $60^{\circ} \mathrm{C}$. Temperature effect on the drying time is observed. The time required for the moisture content to be reduced to values close to zero was $25 \mathrm{~h} 30 \mathrm{~min}, 17 \mathrm{~h} 45 \mathrm{~min}$, $13 \mathrm{~h} 30 \mathrm{~min}, 9 \mathrm{~h} 45 \mathrm{~min}$ and $6 \mathrm{~h} 45 \mathrm{~min}$ for $40,45,50,55$ and $60^{\circ} \mathrm{C}$, respectively. Thus, as the temperature increases, the drying time decreases, and the curves acquire higher slope due to the greater amount of heat transferred from the air to the material. Consequently, an increase occurs in the speed of the migration from the water inside the product to the surface (Baptestini et al., 2015).

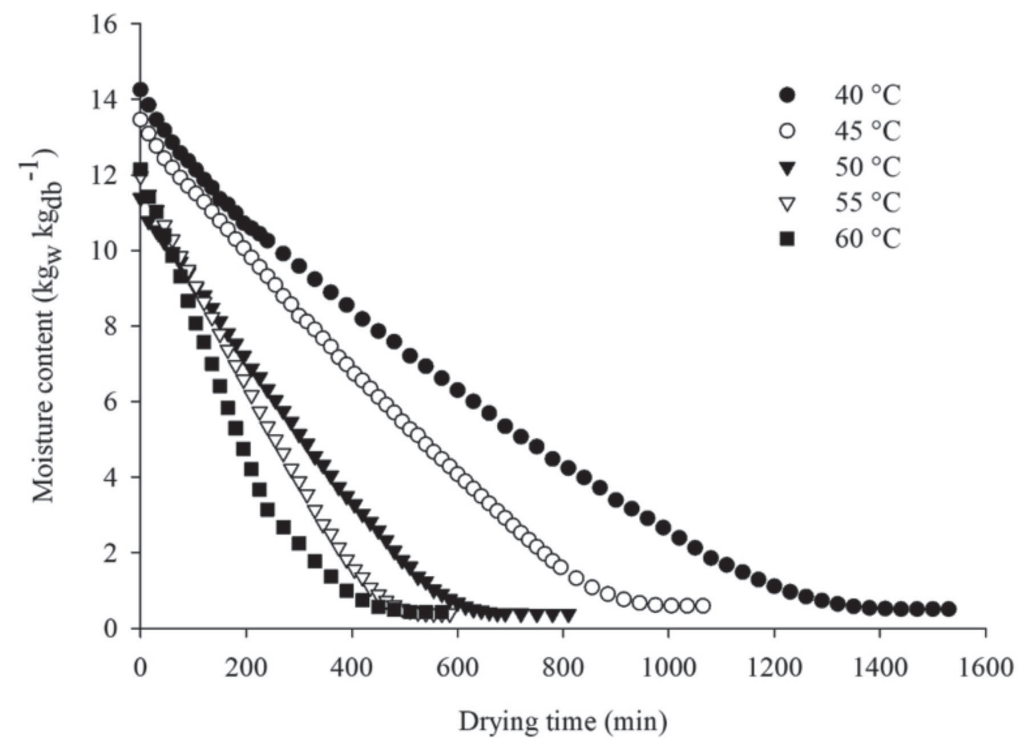

Figure 1: Whey foam drying curves at $40,45,50,55$ and $60{ }^{\circ} \mathrm{C}$.

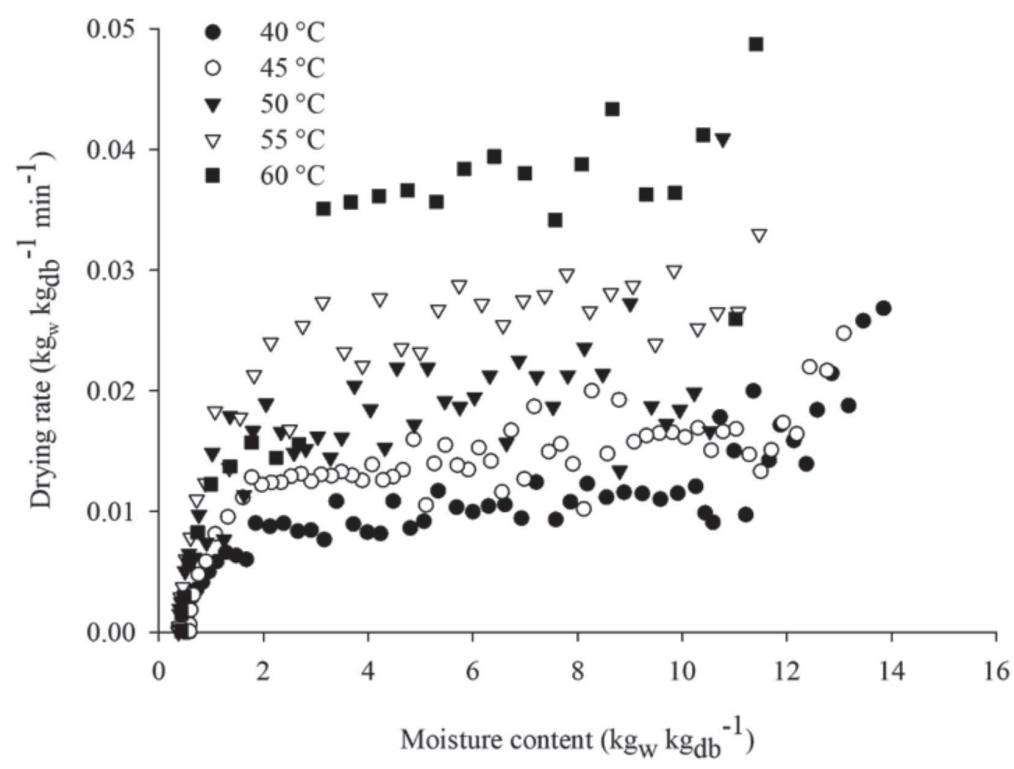

Figure 2: Drying rate curves of whey foam at $40,45,50,55$ and $60{ }^{\circ} \mathrm{C}$. 
Figure 1 also shows the different drying periods, constant rate period and decreasing rate period. According to Park et al. (2007), in the constant rate period, the amount of water available within the product is high. Water evaporates as free water, since its vapor pressure is constant and equal to the pure water vapor pressure at the temperature of the product. The temperature of the product, in turn, is also constant and equal to the wet bulb temperature because heat and mass transfers compensate each other. According to Thuwapanichayanan et al. (2008), water transport inside the foam occurs through capillarity and diffusion of vapor. In addition, Brooker et al. (1992), state that in this period, drying is dependent only on the external conditions of the process: speed, temperature and relative humidity.

Removing water from the whey foam to the exposed surface is not enough to keep the foam wet. Thus, the period of decreasing drying rate ruled by the diffusion mechanism begins. According to Brooker et al. (1992), mass transfer in it does not compensate heat transfer because the internal resistance to water transport becomes greater than the external resistance. This factor limits the reduction of water migration from the interior of the product to its surface. In addition, the temperature of the product increases and can reach the drying air temperature.

Figure 2 shows the curves of drying rate of whey foam. There is a short initial period of material accommodation to the drying process, followed by a long period of constant rate, data parallel to the axis of moisture content, followed by the period of decreasing rate until the moisture content reaches the equilibrium. This confirms the data shown in Figure 1.

Table 2 shows the relative and estimated mean error, coefficient of determination and residual distribution of model adequacy given by Equation 1 from 40 to $60{ }^{\circ} \mathrm{C}$.

According to Resende et al. (2010), despite not being a good parameter to verify the fit of non-linear models, the coefficient of determination usually presents higher values for the models that best fit the experimental data. The values of the coefficient of determination were greater than $99 \%$.

According to Draper \& Smith (1998), the model's ability to reliably describe a specific physical process is inversely proportional to the EME value. Thus, lower values of this variable indicate a better fit of the model to the observed data. Thus, considering this concept, the model is indicated to represent the phenomenon.

Table 2: Relative and estimated mean error, coefficient of determination and residual distribution of model adequacy given by Equation 1 for $40,45,50,55$ and $60{ }^{\circ} \mathrm{C}$

\begin{tabular}{lcccc}
\hline Temperature $\left({ }^{\circ} \mathbf{C}\right)$ & MRE $(\boldsymbol{\%})$ & EME $($ decimal d.b. $)$ & $\mathbf{R}^{2}(\boldsymbol{\%})$ & RD \\
\hline 40 & 7.992 & 0.547 & 98.60 & B \\
45 & 5.185 & 0.251 & 99.61 & B \\
50 & 7.289 & 0.151 & 99.83 & B \\
55 & 7.286 & 0.241 & 99.63 & B \\
60 & 4.905 & 0.076 & 99.97 & B \\
\hline
\end{tabular}

Where, R - random; B - biased.

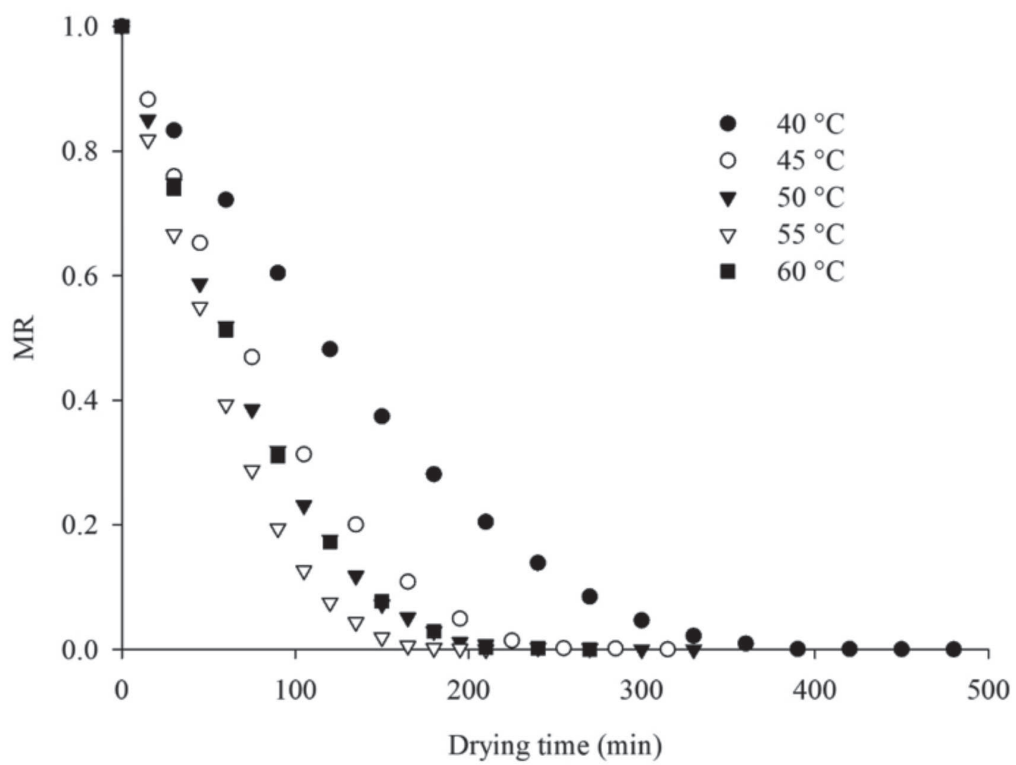

Figure 3: Moisture ratio curves of whey foam drying at $40,45,50,55$ and $60{ }^{\circ} \mathrm{C}$

Rev. Ceres, Viçosa, v. 68, n.4, p. 293-300, jul/aug, 2021 
Table 3: Critical moisture content and critical time

\begin{tabular}{lcc}
\hline Temperature $\left({ }^{\circ} \mathbf{C}\right)$ & $\mathbf{U}_{\mathbf{c}}\left(\mathbf{k g}_{\mathbf{w}} \mathbf{k g}_{\mathbf{d b}}{ }^{-1}\right)$ & $\mathbf{t}_{\mathbf{c}}(\mathbf{m i n})$ \\
\hline 40 & 2.123 & 1050 \\
45 & 2.152 & 750 \\
50 & 2.051 & 480 \\
55 & 2.139 & 375 \\
60 & 2.244 & 300 \\
\hline
\end{tabular}

The mean relative error indicates experimental data deviation from the curve estimated by the model (Kashaninejad et al., 2007). Mohapatra \& Rao (2005) considered that only mathematical models with mean relative error values below $10 \%$ are adequate to represent the process in question. Thus, the model given by Equation 1 is appropriate to describe the serum foamdrying phenomenon.

Table 4: Relative and estimated mean error, coefficients of determination, residue distribution and parameter estimation of whey foam drying curves at $40,45,50,55$ and $60{ }^{\circ} \mathrm{C}$

\begin{tabular}{|c|c|c|c|c|c|}
\hline \multicolumn{6}{|c|}{$40^{\circ} \mathrm{C}$} \\
\hline Model & $\operatorname{MRE}(\%)$ & EME (decimal d.b.) & $\mathbf{R}^{2}(\%)$ & RD & Estimation of parameters \\
\hline 7 & 14.626 & 0.027 & 99.39 & $\mathrm{~B}$ & $\mathrm{a}=1.829 ; \mathrm{k}=0.010$ \\
\hline 8 & 27.940 & 0.049 & 99.75 & $\mathrm{~B}$ & $\mathrm{a}=1.049 ; \mathrm{k}=0.007$ \\
\hline 9 & 5.309 & 0.013 & 99.76 & $\mathrm{R}$ & $\mathrm{a}=1.412 ; \mathrm{k}=0.004 ; \mathrm{b}=-0.410$ \\
\hline 10 & 3.863 & 0.013 & 99.89 & $\mathrm{R}$ & $\mathrm{a}=0.992 ; \mathrm{k}=0.003 ; \mathrm{n}=1.126 ; \mathrm{b}=-0.0004$ \\
\hline 11 & 30.987 & 0.051 & 99.67 & $\mathrm{~B}$ & $\mathrm{k}=0.975$ \\
\hline 12 & 11.284 & 0.024 & 99.50 & $\mathrm{~B}$ & $\mathrm{k}=0.001 ; \mathrm{n}=1.312$ \\
\hline \multicolumn{6}{|c|}{$45^{\circ} \mathrm{C}$} \\
\hline Model & $\operatorname{MRE}(\%)$ & EME (decimal d.b.) & $\mathbf{R}^{2}(\%)$ & RD & Estimation of parameters \\
\hline 7 & 10.130 & 0.017 & 99.80 & $\mathrm{~B}$ & $\mathrm{a}=1.768 ; \mathrm{k}=0.016$ \\
\hline 8 & 21.166 & 0.039 & 98.92 & $\mathrm{~B}$ & $\mathrm{a}=1.043 ; \mathrm{k}=0.012$ \\
\hline 9 & 3.632 & 0.008 & 99.96 & $\mathrm{R}$ & $\mathrm{a}=1.261 ; \mathrm{k}=0.008 ; \mathrm{b}=-0.251$ \\
\hline 10 & 1.534 & 0.004 & 99.99 & $\mathrm{R}$ & $\mathrm{a}=0.999 ; \mathrm{k}=0.006 ; \mathrm{n}=1.112 ; \mathrm{b}=-0.0004$ \\
\hline 11 & 24.311 & 0.042 & 98.57 & $\mathrm{~B}$ & $\mathrm{k}=0.011$ \\
\hline 12 & 8.994 & 0.016 & 99.82 & $\mathrm{~B}$ & $\mathrm{k}=0.004 ; \mathrm{n}=1.232$ \\
\hline \multicolumn{6}{|c|}{$50{ }^{\circ} \mathbf{C}$} \\
\hline Model & $\operatorname{MRE}(\%)$ & EME (decimal d.b.) & $\mathbf{R}^{2}(\%)$ & RD & Estimation of parameters \\
\hline 7 & 11.190 & 0.023 & 99.55 & $\mathrm{R}$ & $\mathrm{a}=1.819 ; \mathrm{k}=0.019$ \\
\hline 8 & 23.875 & 0.044 & 98.25 & $\mathrm{~B}$ & $\mathrm{a}=1.052 ; \mathrm{k}=0.014$ \\
\hline 9 & 6.186 & 0.017 & 99.77 & $\mathrm{R}$ & $\mathrm{a}=1.304 ; \mathrm{k}=0.008 ; \mathrm{b}=-0.294$ \\
\hline 10 & 4.620 & 0.016 & 99.83 & $\mathrm{R}$ & $\mathrm{a}=0.994 ; \mathrm{k}=0.006 ; \mathrm{n}=1.159 ; \mathrm{b}=-0.001$ \\
\hline 11 & 27.111 & 0.047 & 97.83 & $\mathrm{~B}$ & $\mathrm{k}=0.013$ \\
\hline 12 & 8.917 & 0.021 & 99.62 & $\mathrm{R}$ & $\mathrm{k}=0.004 ; \mathrm{n}=1.287$ \\
\hline \multicolumn{6}{|c|}{$55^{\circ} \mathrm{C}$} \\
\hline Model & $\operatorname{MRE}(\%)$ & EME (decimal d.b.) & $\mathbf{R}^{2}(\%)$ & RD & Estimation of parameters \\
\hline 7 & 13.287 & 0.024 & 99.54 & $\mathrm{~B}$ & $\mathrm{a}=1.833 ; \mathrm{k}=0.024$ \\
\hline 8 & 28.480 & 0.048 & 98.13 & $\mathrm{~B}$ & $\mathrm{a}=1.048 ; \mathrm{k}=0.017$ \\
\hline 9 & 8.370 & 0.018 & 99.77 & $\mathrm{R}$ & $\mathrm{a}=1.302 ; \mathrm{k}=0.011 ; \mathrm{b}=-0.293$ \\
\hline 10 & 5.068 & 0.016 & 99.85 & $\mathrm{R}$ & $\mathrm{a}=0.993 ; \mathrm{k}=0.007 ; \mathrm{n}=1.185 ; \mathrm{b}=-0.001$ \\
\hline 11 & 31.770 & 0.050 & 97.76 & B & $\mathrm{k}=0.017$ \\
\hline 12 & 9.334 & 0.021 & 99.64 & $\mathrm{~B}$ & $\mathrm{k}=0.005 ; \mathrm{n}=1.309$ \\
\hline \multicolumn{6}{|c|}{$60{ }^{\circ} \mathrm{C}$} \\
\hline Model & MRE(\%) & EME (decimal d.b.) & $\mathbf{R}^{2}(\%)$ & RD & Estimation of parameters \\
\hline 7 & 7.586 & 0.019 & 99.77 & $\mathrm{R}$ & $\mathrm{a}=1.865 ; \mathrm{k}=0.019$ \\
\hline 8 & 20.372 & 0.052 & 98.26 & $\mathrm{~B}$ & $\mathrm{a}=1.036 ; \mathrm{k}=0.013$ \\
\hline 9 & 4.654 & 0.015 & 99.89 & $\mathrm{R}$ & $\mathrm{a}=1.405 ; \mathrm{k}=0.007 ; \mathrm{b}=-0.398$ \\
\hline 10 & 1.487 & 0.009 & 99.85 & $\mathrm{R}$ & $\mathrm{a}=0.999 ; \mathrm{k}=0.005 ; \mathrm{n}=1.196 \mathrm{~b}=-0.00005$ \\
\hline 11 & 21.845 & 0.050 & 98.00 & $\mathrm{~B}$ & $\mathrm{k}=0.013$ \\
\hline 12 & 5.116 & 0.015 & 99.86 & $\mathrm{R}$ & $\mathrm{k}=0.003 ; \mathrm{n}=1.329$ \\
\hline
\end{tabular}

Where, R: random; B: biased. 
Finally, the residue distribution analysis is necessary for a correct evaluation of the model. Even when the statistical parameters show good results, the model may be ineffective if it presents a tendentious residue distribution. This was observed for the model given by Equation 1. Thus, the model is not able to describe correctly whey drying and to determine the transition point between the period of constant and decreasing drying rate; however, it provides indications of where it occurs. In contrast, the same model was able to describe the kinetics of soursop foam drying (Baptestini et al., 2015).

Table 3 shows the values of the critical moisture content and the critical time established from the indications given by the model of Equation 1, the analysis of drying curves and the statement of Brooker et al. (1992) that the transition between drying period at constant and decreasing rate occurs in moisture content from 2.33 to $3.00 \mathrm{kga} \mathrm{kgms}-1$. Critical time showed an expected trend. As the drying temperature increased, the critical time decreased.

Figure 3 shows the moisture ratio curves of whey foam drying at $40,45,50,55$ and $60^{\circ} \mathrm{C}$. They represent the water loss due to time for the period of decreasing drying. As the temperature increases, the drying time decreases.

For the curves of Figure 3, was adjusted the mathematical models reported in the literature that describe the drying phenomenon. The results are shown in Table 4.

The Logarithm and Midilli models, as well as the Exponential models of two terms and Page are able to describe the drying phenomenon of whey foam only at $60^{\circ} \mathrm{C}$, for the same justification of the suitability of the model given by Equation 1 .

Kadam \& Balasubramanian (2011) studied the kinetics of foam mat drying of tomato juice and concluded that the Logarithm model was the one that better described the drying of the product. Soares (2009), in his work on the characterization of additives for drying of Arazá (Eugenia stipitata) in foam mat, used more solid criteria to choose the model and obtained better fit for the Two Terms model. Baptestini et al. (2015) state that the Midilli model was the most appropriate to describe the kinetics of soursop foam drying.

The effective diffusion coefficient of whey foam grew with increasing temperature and showed a linear correlation (Table 5). This was expected because by raising the temperature, the viscosity of water, which is a measure of fluid resistance to the flow, decreases due to the reduction of the cohesive forces between the molecules. Such fact was also observed by Thuwapanichayanan et al. (2008) and Kadam \& Balasubranian (2011).

Table 5: Effective diffusion coefficient $\left(\mathrm{m}^{2} \mathrm{~s}^{-1}\right)$ of whey foam dried at $40,45,50,55$ and $60{ }^{\circ} \mathrm{C}$, regression equation as a function of the temperature $(\mathrm{T})$ and its coefficient of determination

\begin{tabular}{lcccc}
\hline \multicolumn{5}{c}{ Temperature $\left({ }^{\circ} \mathbf{C}\right)$} \\
\hline 40 & 45 & 50 & 55 & 60 \\
$2.751 \times 10^{-10}$ & $3.394 \times 10^{-10}$ & $5.277 \times 10^{-10}$ & $6.616 \times 10^{-10}$ & $8.525 \times 10^{-10}$ \\
& $D_{e f}=-9 \times 10^{-10}+3 \times 10^{-11} \times T$ & & $\mathrm{R} 2=97.99 \%$ & \\
\hline
\end{tabular}

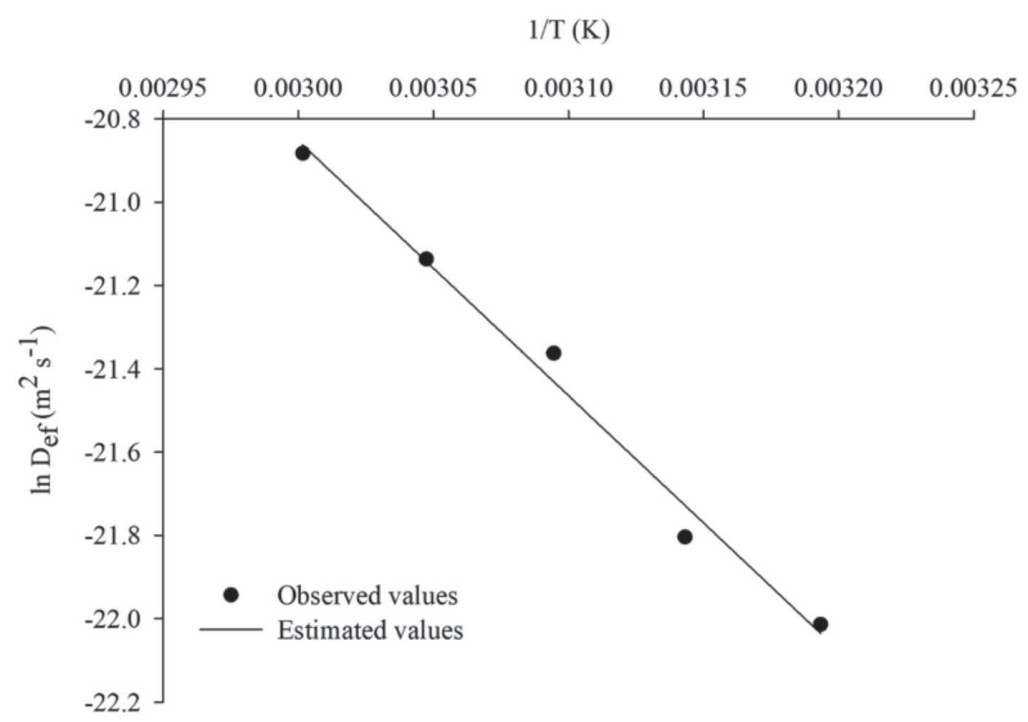

Figure 4: Representation of Ahrrenius.

Rev. Ceres, Viçosa, v. 68, n.4, p. 293-300, jul/aug, 2021 
The variation in the effective diffusion coefficient caused by the drying temperature is described by the ratio of Ahrrenius (Figure 4).

The slope of this curve gives the ratio $\mathrm{Ea} / \mathrm{R}$, while its intersection with the $\mathrm{y}$-axis indicates the value of $\mathrm{D}_{0}$. Therefore, the relation of Ahrrenius can be written as:

$D_{e f}=8.15 \times 10^{-2} \exp \left(\frac{50840.11}{R T_{a}}\right)$

The activation energy was $50.84 \mathrm{~kJ} \mathrm{~mol}^{-1}$. It was slightly higher than the values observed by Thuwapanichayanan et al. (2008) and Baptestini et al. (2015). In the drying processes, the lower the activation energy, the greater the water diffusivity in the product. In other words, less energy will be required for the physical transformation to occur, which in this case is the transformation of free liquid water into vapor (Corrêa et al., 2010).

\section{CONCLUSIONS}

The model used for determining the transition point between the period of constant drying rate and that of decreasing drying rate did not adjust well to the experimental data on whey foam drying. However, the Logarithm and Midili models, as well as the Exponential models of two terms and Page are able to describe the phenomenon of whey foam drying only at $60{ }^{\circ} \mathrm{C}$. The effective diffusion coefficient increased with the elevation of drying temperature and activation energy of $50.84 \mathrm{~kJ}$ mol-1.

\section{ACKNOWLEDGEMENTS, FINANCIAL SUPPORT AND FULL DISCLOSURE}

The authors would like to thank the Coordenação de Aperfeiçoamento Pessoal de Nível Superior (CAPES Brazil) (Coordination for the Improvement of Higher Education Personnel) for essential support and financial aid to publish this article (Finance Code 001); and the Conselho Nacional de Desenvolvimento Científico e Tecnológico (CNPq - Brazil) (National Counsel of Technological and Scientific Development) for funding the scholarship.

The authors declare that there is no conflict of interest in the conduction and publication of the work.

\section{REFERENCES}

Alves MP, Moreira RO, Rodrigues Júnior PH, Martins MCF, Perrone IT \& Carvalho AF (2014) Soro de leite: tecnologias para o processamento de co-produtos. Revista do Instituto de Laticínios Cândido Tostes, 69:212-226.

Baptestini FM, Corrêa PC, Junqueira MS, Ramos AM, BustosVanegas JD \& Costa CF (2015) Modelagem matemática da secagem de espuma de graviola. Revista Brasileira de Engenharia Agrícola e Ambiental, 19:1203-1208.
Bastos DS, Soares DMBG, Araújo KGL \& Verruma-Bernardi MR (2005) Desidratação da Polpa de Manga "Tommy Atkins" Utilizando a Técnica de "Foam-Mat Drying" - Avaliações Químicas, Físico-químicas e Sensoriais. Brazilian Journal of Food Technology, 8:283-290.

Brooker DB, Bakker-Arkema FW \& Hall CW (1992) Drying and storage of grains and oilseeds. Westport, The AVI Publishing Company. 450p.

Corrêa PC, Oliveira GHH, Botelho FM, Goneli ALD \& Carvalho FM (2010) Modelagem matemática e determinação das propriedades termodinâmicas do café (Coffea Arábia L.) durante o processo de secagem. Revista Ceres, 57:595-601.

Draper NR \& Smith H (1998) Applied regression analysis. New York, John Wiley \& Sons. 736p.

Fellows P (2006) Desidratação. In: Fellows P (Ed.) Tecnologia do processamento de alimentos - Princípios e práticas. 2a ed. Porto Alegre, Artmed. p. 309-340.

Foodsnews (2018) A produção de queijos no país deve crescer em 2018! Available at: <http://www.foodnewsoficial.com.br/mercado/producao-de-queijos/>. Accessed on: July 02nd, 2018.

Henderson SM \& Pabis S (1961) Grain drying theory: temperature effect on drying coefficient. Journal of Agricultural Engineering Research, 6:169-174.

Kadam DM \& Balasubramanian S (2011) Foam mat drying of tomato juice. Journal of Food Processing and Preservation, $35: 488-495$.

Kashaninejad M, Mortazavi A, Safekordi A \& Tabil LG (2007) Thin-layer drying characteristics and modeling of pistachio nuts. Journal of Food Engineering, 78:98-108.

Lewis WK (1921) The drying of solid materials. Journal of Industrial \& Engineering Chemistry, 13:427-433.

Midilli A, Kucuk H \& Yapar Z (2002) A New model for single layer drying. Drying Technology, 20:1503-1513.

Mohapatra D \& Rao PSA (2005) Thin layer drying model of parboiled wheat. Journal of Food Engineering, 66:513-518.

Page GE (1949) Factors influencing the maximum rates of air drying shelled corn in thin layers. West Lafayette, Purdue University. $44 \mathrm{p}$.

Park KJ, Antonio GC, Oliveira RA \& Park KJB (2007) Conceitos de processos e equipamentos de secagem. Campinas, UNICAMP. $121 \mathrm{p}$.

Perrone IT (2010) Soro de leite: concentração, cristalização da lactose e secagem. Tese de Doutorado. Universidade Federal de Viçosa, Viçosa. 95p.

Perrone IT, Pereira JPF \& Carvalho AF (2011) Aspectos tecnológicos da fabricação de soro em pó: uma revisão. Revista do Instituto de Laticínios Cândido Tostes, 66:23-30.

Reis RC, Côrrea PC, Devilla IA, Santos ES, Ascheri DPR, Servulo ACO \& Souza ABM (2013) Drying of yam starch (Discorea ssp.) and glycerol filmogenic solutions at different temperatures. Food Science and Technology, 50:651-656.

Resende O, Rodrigues S, Siqueira VC \& Arcanjo RV (2010) Cinética de secagem de clones de café (Coffea canefora Pierre) em terreiro de chão batido. Acta Amazonica, 40:247-256.

Sharaf-Eldeen YI, Blaisdell JL, Hamdy MY (1980) A model for ear corn drying. Transactions of the American Society of Agricultural Engineers, 23:1261-1265.

Soares EC (2009) Caracterização de aditivos para secagem de araçá-boi (Eugenia stipitata Mc Vaugh) em leito de espuma. Dissertação de Mestrado. Universidade Estadual do Sudoeste da Bahia, Itapetinga. 88p.

Rev. Ceres, Viçosa, v. 68, n.4, p. 293-300, jul/aug, 2021 
Stupa MV, Platonov EK \& Milkhailov VT (2003) Mathematical model of drying of granulated anid. Fibre Chemistry, 35:233236.

Thuwapanichayanan R, Prachayawarakorn S \& Soponronnarit S (2008) Drying characteristics and quality of banana foam mat. Journal of Food Engineering, 86:573-583.
Yagcioglu A, Degirmencioglu A \& Cagatay F (1999) Drying characteristics of laurel leaves under different conditions. In: 7th International Congress on Agricultural Mechanization and Energy, Adana. Proceedings, Cukurova University. p. 565-569. 